\title{
HOW FUTURE SEA LEVEL RISE WILL AFFECT SOUTH DUNEDIN
}

\author{
PHILIP J. GLASSEY \\ GNS Science, New Zealand
}

\begin{abstract}
The southern part of Dunedin City, New Zealand, is built over an estuarine marsh, close to sea level and is vulnerable to increased flooding from raised groundwater levels, which will only worsen with predicted sea level rise. Limited data indicate that this area may also be subsiding via either sediment consolidation or tectonism. The underlying sediments amplify seismic waves with the potential to liquefy during strong earthquake shaking. Dunedin is a hazardous place to live and about 2,600 homes are less than $50 \mathrm{~cm}$ above mean sea level. Past mining of a dune barrier led to inundation of parts of the city and without the re-established dune barrier, this community would be unprotected. In June 2015, a moderate rainfall event caused NZD 26 million damage through flooding, primarily related to deteriorating and poorly maintained drainage infrastructure. However, the groundwater level here is near the surface ( $0-1 \mathrm{~m}$ depth) and shows tidal fluctuations, which influence the degree of flooding. Reduced storm water storage, related to the increased groundwater levels due to sea level rise, will result in more frequent flooding and of greater magnitude over time. Engineering solutions such as increased pumping capacity and creation of storage areas will be required at considerable cost and disruption to the city. There are difficult decisions to be made about the sustainability of this low-lying coastal community in terms of investment and protection or abandonment of this area. While fundamentally social and economic issues, such decisions should be informed by rigorous technical assessments and investigation and more extensive monitoring systems.
\end{abstract}

Keywords: flooding, groundwater, New Zealand, sea level rise, South Dunedin

\section{INTRODUCTION}

South Dunedin, an urban area in New Zealand (Fig. 1), is low-lying land, having been reclaimed from coastal marshes and intertidal deposits since European settlement in the late 1800 s. It is one among a number of coastal urban areas in New Zealand that faces the challenge of predicted sea level rise. At least 32,000 homes in New Zealand are less than $150 \mathrm{~cm}$ above sea level, and 5,500 homes only $50 \mathrm{~cm}$ above mean sea level in nine urban areas across New Zealand [1]. About half of the latter homes are located in the city of Dunedin (Fig. 1).

The latest IPCC5 modelling indicates that sea level rise could accelerate over the next 100 years and be higher than the $50 \mathrm{~cm}$ currently used in New Zealand Planning guidelines [2, 3] to 2100 and therefore many of the 32,000 New Zealand homes may be threatened by inundation and flooding due to raised groundwater level.

In addition to sea level rise, coastal urban areas across New Zealand are subject to tectonic forces (uplift and/or subsidence and earthquake shaking) and tsunami and have varying geology, sediment supply and deposition rates, and climate conditions. Communities and local governments will be facing difficult decisions about the sustainability of coastal margins in terms of long-term management, protection or abandonment of developed areas in the next 50 years or so. What information will they require to ensure that the decisions they make are sustainable beyond a 100-year planning period? Do they invest in upgrading infrastructure in such vulnerable areas and for what time frames? Do they understand the environment that they are trying to protect, in terms of the long-term tectonic regime, groundwater flow and interaction with the sea? Fundamentally, these are economic and social issues, but they should be informed by rigorous investigation, technical assessments and more extensive 


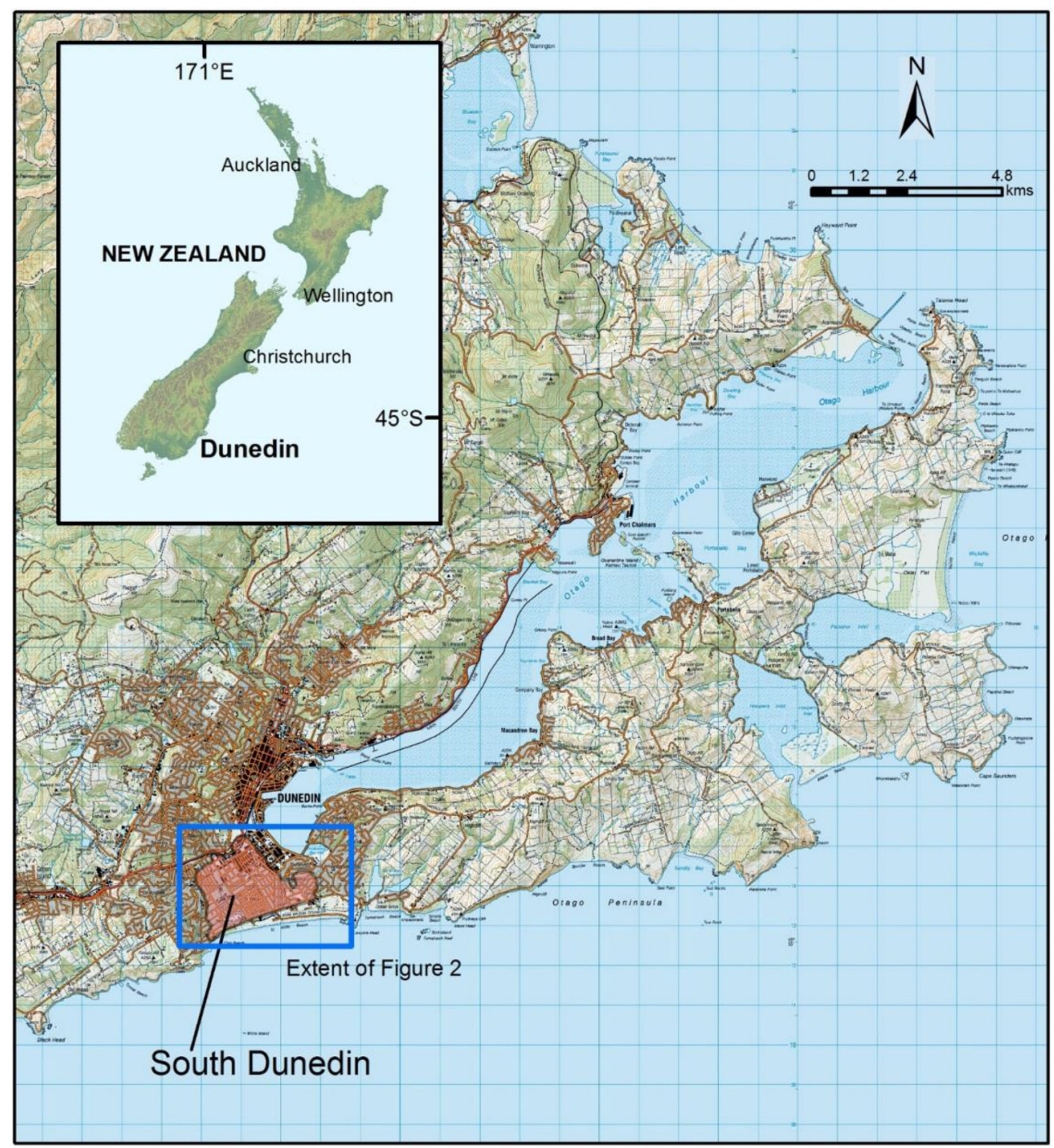

Figure 1: Location of South Dunedin, New Zealand (topography cc LINZ).

monitoring systems. This article will outline some of the environmental challenges that South Dunedin faces and some of the management issues that will need to be considered in dealing with these challenges.

In raising awareness of the technical and social issues, the public of Dunedin will engage in the decision-making about the investigations needed and the cost of and impact of potential solutions to a long-term threat to the city. This article provides a summary of the environment and the social issues to date, based on a number of disparate studies.

\section{SOUTH DUNEDIN}

South Dunedin is built over an estuarine marsh that was reclaimed by European settlers from about 1860. Some of the reclamation material was taken from the ocean beach dune barrier [4]. Several attempts have been made at building a sea wall at the western end of the beach to 
form a 'promenade' - the current wall built in 2000 has been undermined in places and has resulted in erosion of the modified and over-steepened dunes beyond the eastern end of the wall (Fig. 2). Sea flooding, due to dune sand removal, affected parts of the reclaimed land in the 1880 s, and a number of interventions to arrest erosion and retain the dune barrier, including bringing fill to raise the barrier, have had varying effects.

The harbour margin was reclaimed in 1960s, extending the 1850 shoreline to the present rock wall shoreline (Fig. 3), and was raised above the earlier reclamations to the west, thereby forming a barrier. South Dunedin is now a low-lying basin (Fig. 3) and storm water and wastewater have to be pumped out of the basin.

Being the largest portion of flat land (approximately $600 \mathrm{ha}$ ) in the newly formed settlement of Dunedin, the reclamation was soon occupied by industrial manufacturing, engineering

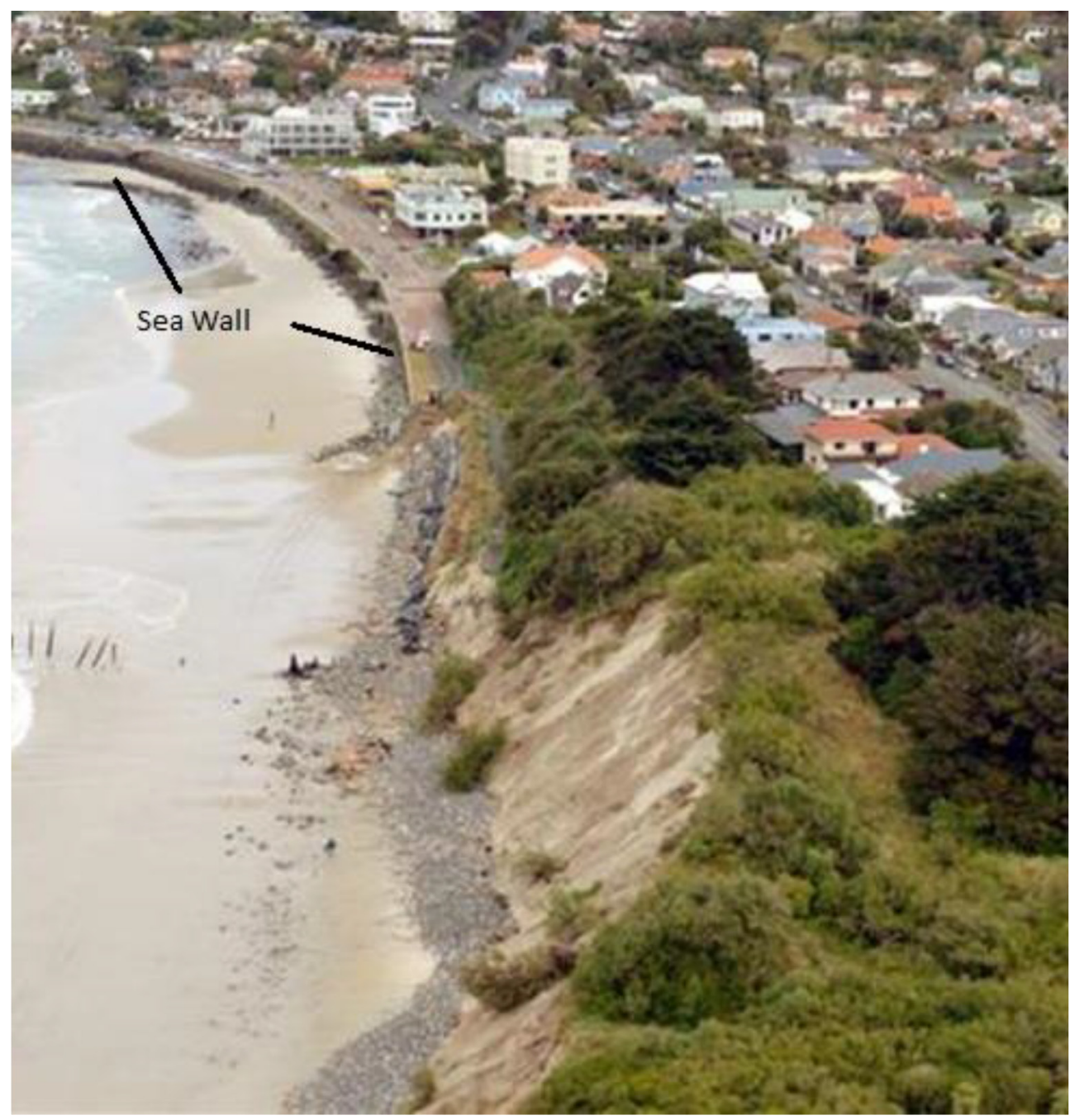

Figure 2: The St Clair sea wall and erosion beyond the eastern end of the wall (foreground). Poles which are remnants of past efforts to stop erosion here are visible in the surf zone (middle left) (Otago Daily Times). 


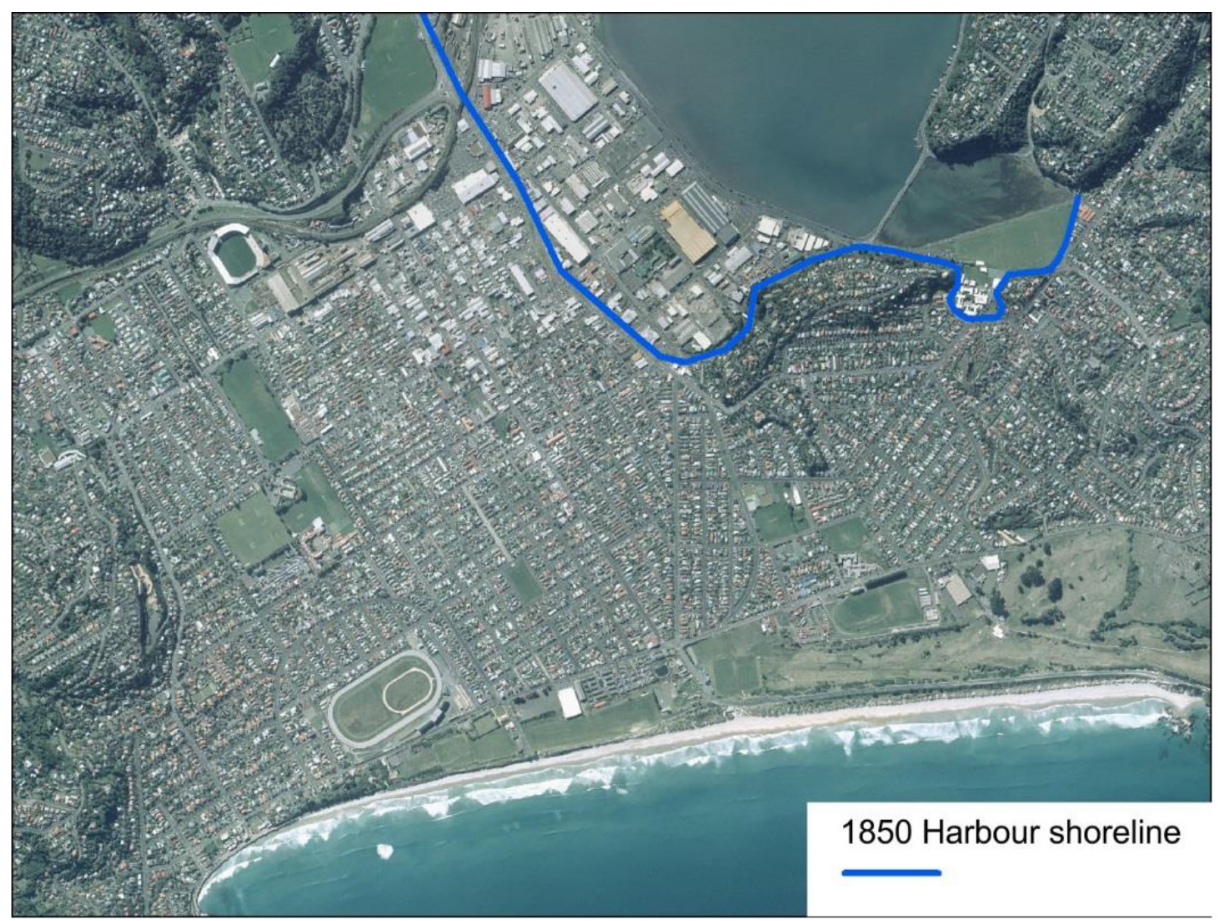

(a)

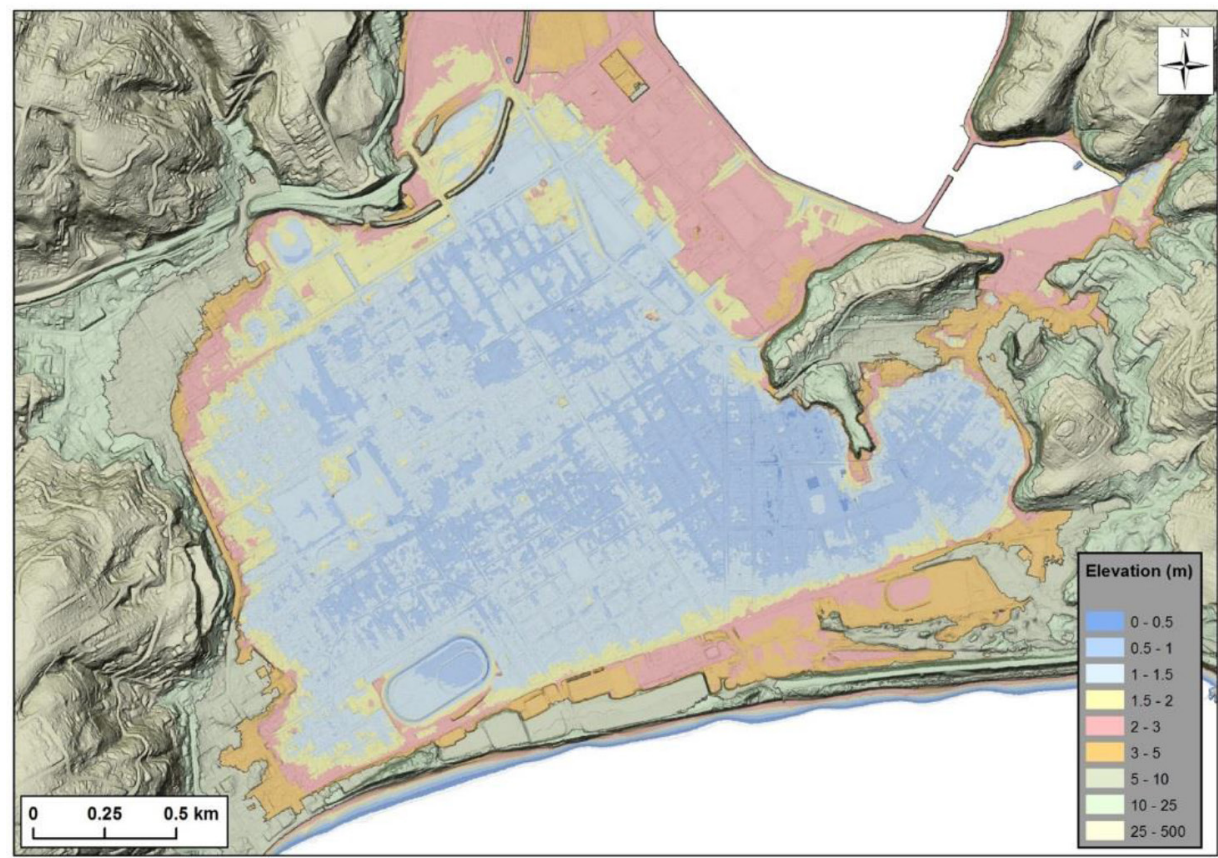

(b)

Figure 3: (a) Urban development of South Dunedin and the 1850 harbour shoreline and (b) South Dunedin Elevation Model generated from LiDAR. The blue areas are at or up to $1.5 \mathrm{~m}$ above mean sea level ([4]). 
works and warehouses, and high-density worker cottages. Approximately 4,300 dwellings are now located within South Dunedin $[4,5]$ and approximately 10,000 people are living in this area. There is a high proportion of elderly people ( $>65$ years old) when compared to the national average [4]. About 2,600 homes are at an elevation of $0-1 \mathrm{~m}$ above mean sea level [1].

Other infrastructure in South Dunedin includes 12 schools ( 3 high schools), at least 6 early childhood centres, parks and sports grounds, key infrastructure such as an electricity substation, wastewater treatment plant for Dunedin City and a storm water pumping station, and a number of public buildings and commercial buildings.

\section{IMPACTS OF SEA LEVEL RISE}

\subsection{Sea level rise}

The long-term tide record for Dunedin (Fig. 4) is intermittent but shows a general trend of sea level rise at a rate of $1.36 \mathrm{~mm}$ per annum over a period of 110 years (Fig. 4). It should be noted that this is not absolute sea level change, and GPS data over the past 15 years or so indicate that the land appears to sinking [4]. Therefore, much of the measured relative sea level rise may be attributable to sinking land, not absolute sea level rise. Satellite radar suggests that the sinking is not uniform. For example, much of South Dunedin may be sinking faster than at the tide gauge/GPS sites which are not located within south Dunedin. Effects of sinking need to be added to absolute sea level rise scenarios to determine relative sea levels.

The New Zealand Ministry for the Environment have developed sea level rise guidelines for urban planning based on IPCC projections (Fig. 5). It is anticipated that sea level rise will accelerate over the next 100 years or so as polar ice caps melt and the oceans expand.

\subsection{Groundwater}

Shallow groundwater is measured and monitored in four boreholes established to a depth of $6 \mathrm{~m}$, by the Otago Regional Council (ORC) in 2009. Another 13, 3-m-deep, bores monitored groundwater between 2012 and 2013 as part of a university thesis [6]. The median

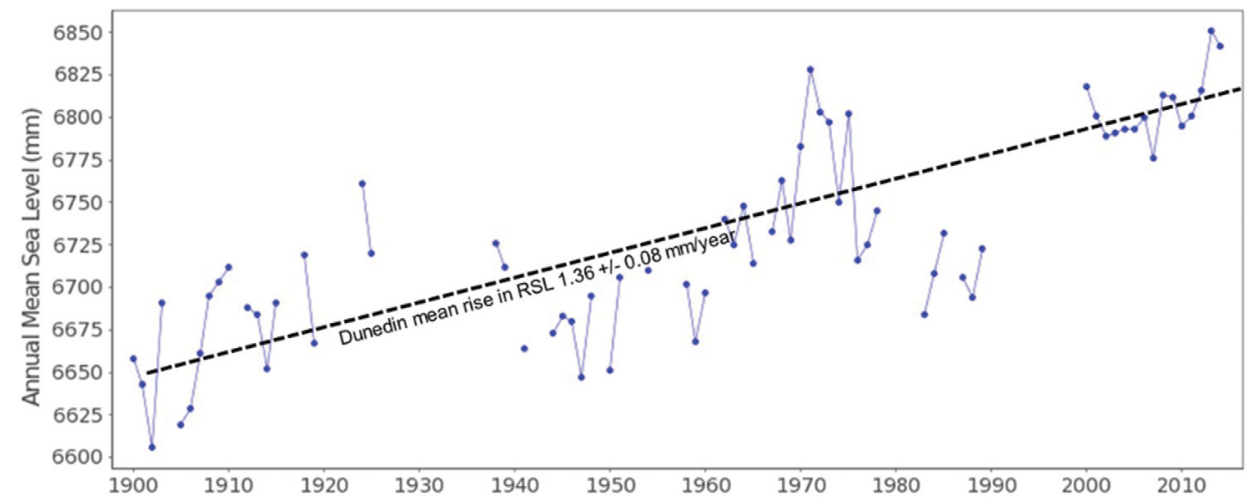

Figure 4: Annual mean sea levels for the tide gauge in Otago Harbour from 1901 to 2015. Mean annual sea level rise in this period is $1.36 \mathrm{~mm} /$ year (source: Permanent Service for Mean Sea Level, http://www.psmsl.org/). 


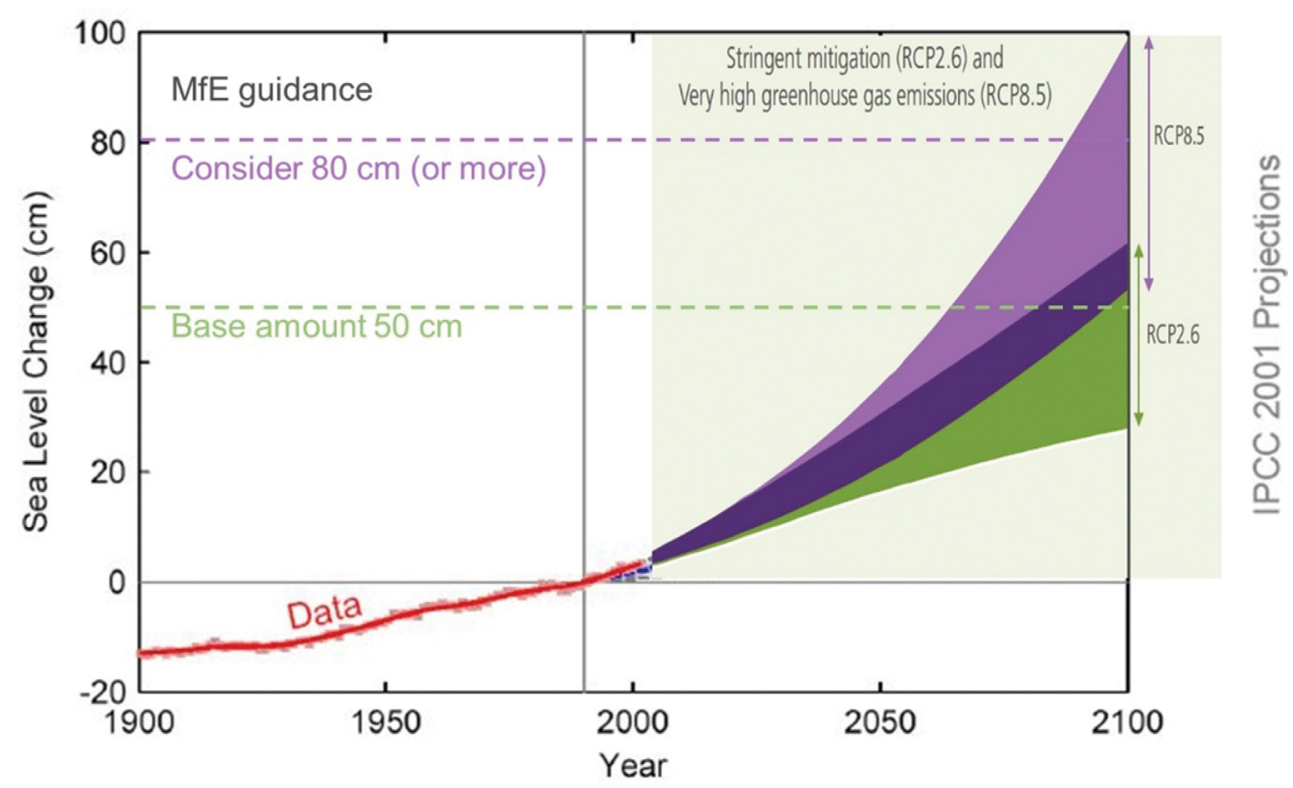

Figure 5: The existing sea level trend for Dunedin (red, left) and the Ministry for the Environment [2] future sea level change guidance for land use and urban planning in New Zealand to 2100 (right), based on IPCC projections.

groundwater levels observed in the bores are between 0.55 and $0.7 \mathrm{~m}$ above MSL (about $0.5-$ $0.9 \mathrm{~m}$ below ground level). The groundwater level is extremely sensitive to rainfall, rising rapidly and sometimes reaching levels above the ground surface. Sea level also influences groundwater levels (Fig. 6), particularly closer to the ocean dune margin.

Also influencing the shallow groundwater level is the aged and damaged storm water and wastewater pipe networks, generally buried at depth below mean groundwater level. The leaky pipe networks are considered to suppress groundwater levels in general, and pumping station data shows that the pipe networks are surcharged during periods of heavy rainfall and associated elevated groundwater levels [4].

As shown in Fig. 6, there is also a direct influence of tides on the shallow aquifer beneath South Dunedin, with higher amplitude fluctuations closer to the ocean margin. In the example provided (Kennedy St bore), the groundwater cycle lags the tide cycle by about 2 hours and fluctuates $0.25 \mathrm{~m}$ (about 17\%) of the tidal range [4,5] but other bores indicate that this fluctuation decays with distance from the sea.

\subsection{Flooding}

South Dunedin is a basin of low elevation with relatively high groundwater levels and would be expected to be prone to flooding. However, apart from flooding in 1923 (Fig. 7), there has been no extensive flooding of South Dunedin until June 2015. The water entering the enclosed basin is removed by pumping. 


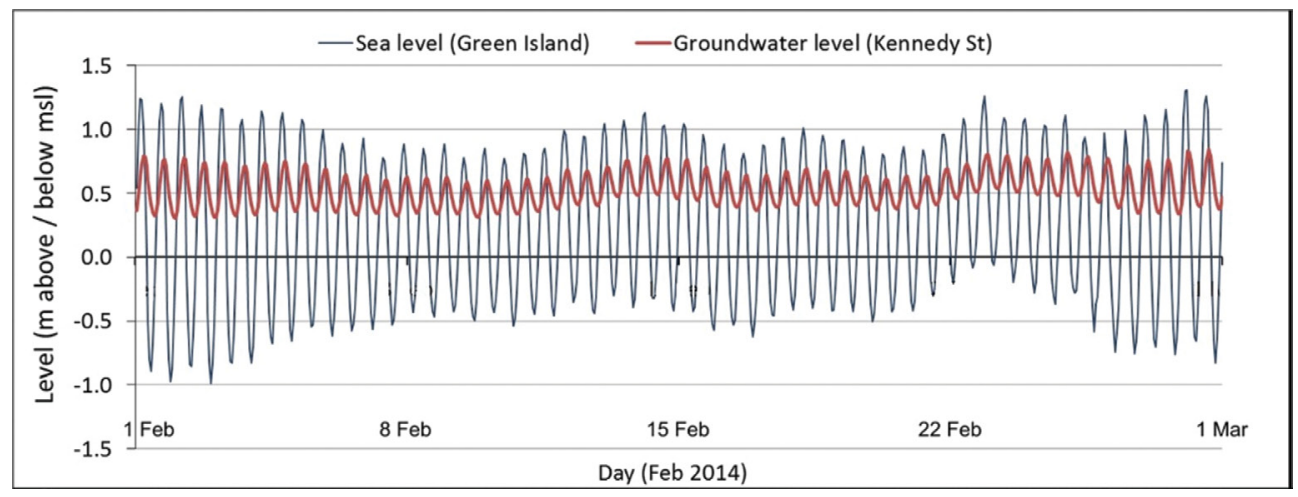

Figure 6: Groundwater data for a monitored bore in South Dunedin (red) for the month of February 2014, plotted against the tidal signature at a nearby ocean tide gauge for the same period (source $[4,5]$ ).

In June 2015 flooding of parts of South Dunedin (Fig. 8), as a result of a relatively high intensity rainfall, caused an estimated damage of NZD\$26 M (approximately USD \$18 M). About $120 \mathrm{~mm}$ of rain fell in a 24-hour period with a rainfall duration return period of between 20 and 50 years. Considerable debate about the cause of the flooding ensued, and a lack of maintenance of storm water mud tanks, along with modifications made to the storm water pumping screens were deemed to have contributed significantly to the flooding. However, elevated groundwater levels, exacerbated by the tidal influence near the coast, also contributed to the flooding.

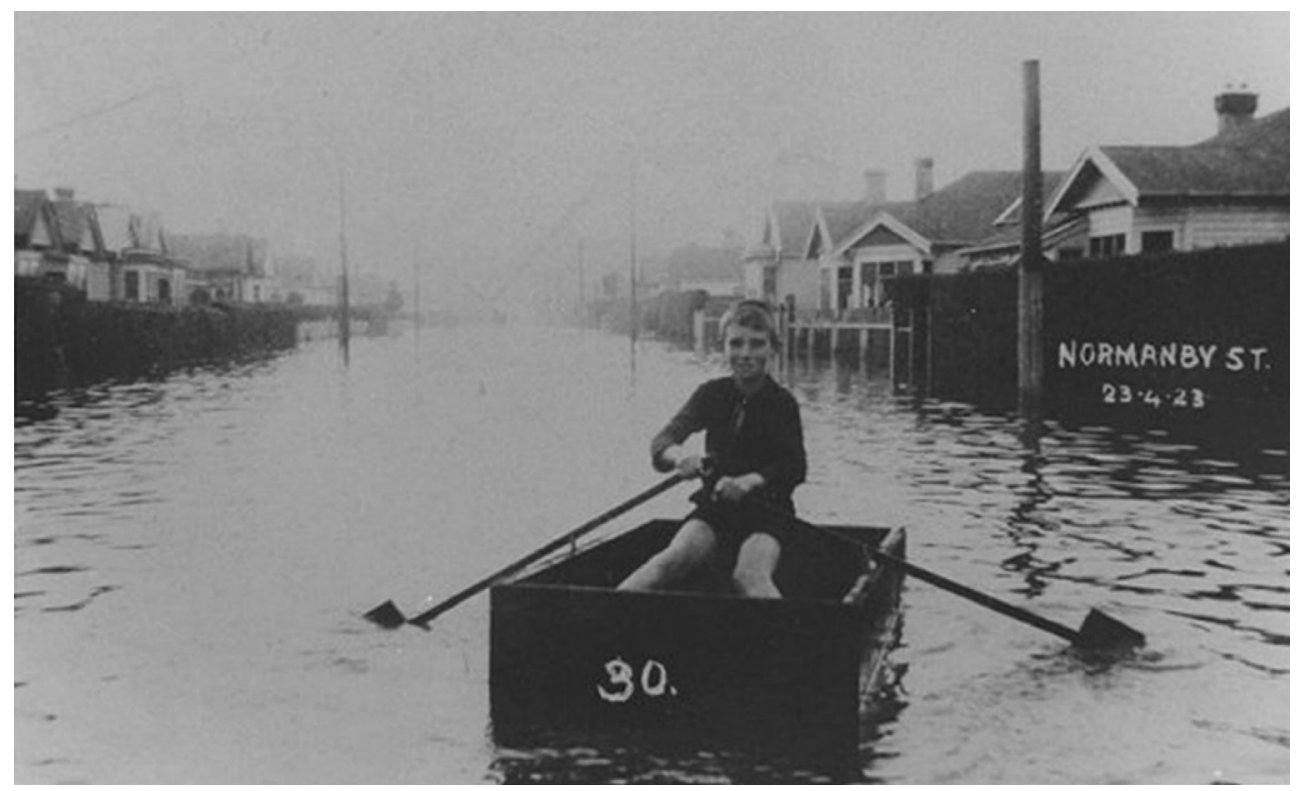

Figure 7: Flooding in South Dunedin, 1923 (source: Otago Daily Times). 


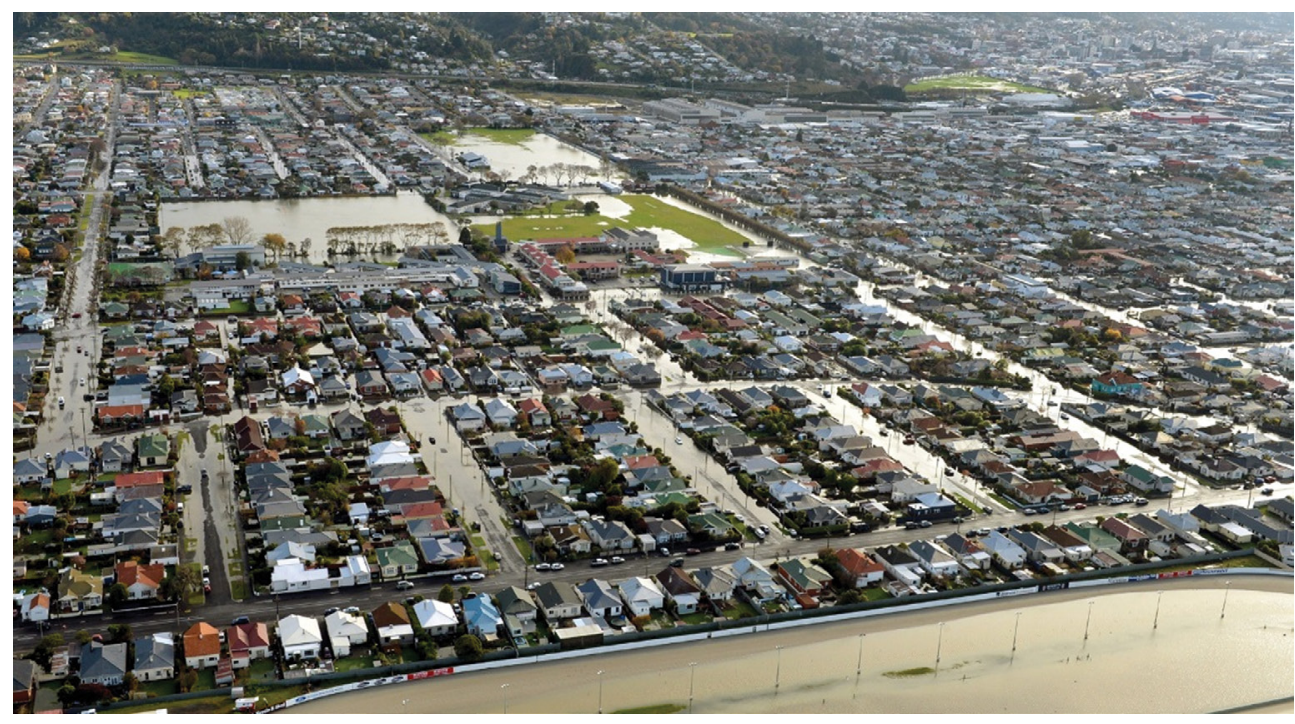

Figure 8: Flooding of South Dunedin June 2015 (source: Otago Daily Times).

\subsection{Future flood scenarios}

Rising sea level and groundwater levels will considerably decrease the availability of storage of run-off that enters the basin. Raised groundwater levels due to rising sea level and tectonic settlement will have a significant effect on future flooding of South Dunedin. To date, various flood modelling scenarios [5, 7] have been developed for a range of sea level rise scenarios using different groundwater models. The models from two different organizations vary greatly in the extent of flooding and the depths of water, reflecting the uncertainty in the existing groundwater model. The model shown in Fig. 9 shows areas where above ground ponding is likely to occur with $0.6 \mathrm{~m}$ of sea level rise.

\section{PLANNING AND MANGEMENT ISSUES}

The local government now faces a number of issues regarding the future of South Dunedin. The debate about long-term management of the impacts of sea level rise has only just begun and is likely to continue for the next decade or so. The issues are not South Dunedin's alone, and belong to the city's population at large who play sport, use the beaches, work, shop and pass through South Dunedin to get from the city centre to more elevated suburbs.

There was outrage from the community regarding the neglect of the existing storm water system that was considered a major cause of the 2015 flooding. Accordingly, the local government is investigating to upgrade the storm water networks extensively. There is debate about the design period of such a system given the sea level rise predictions and flood modelling scenarios described earlier, and the extent of influence a better pipe network will have on the groundwater level.

In 2014 a commissioned study [7] modelled the pumping of groundwater to keep it at a 2010 level, for 2090 sea level scenarios. The minimum sea level rise scenario was costed at NZD\$75 million to install drains and pumping equipment, and NZD\$4 million per annum in maintenance costs and servicing of the pumps. To keep groundwater at the 2010 level for 


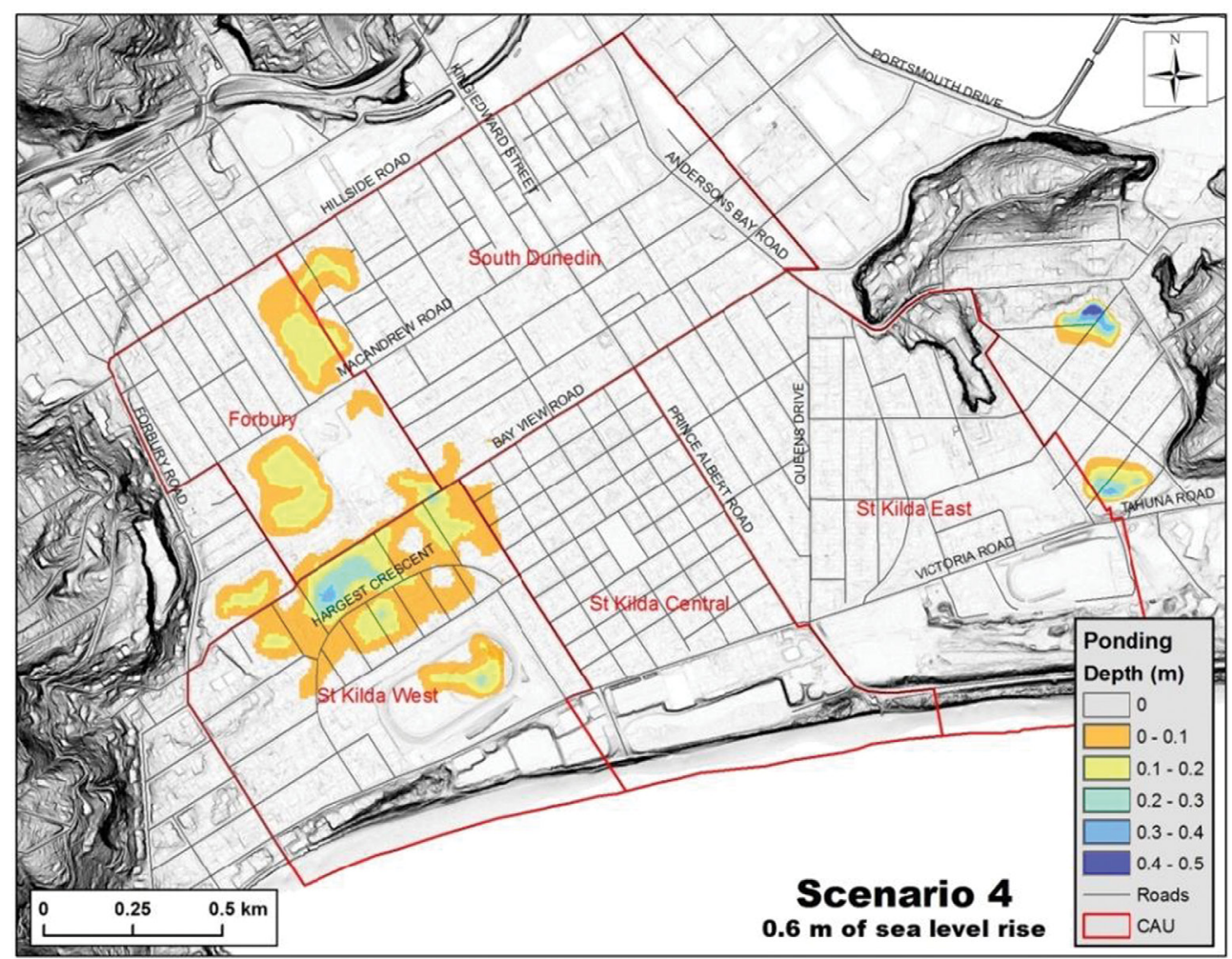

Figure 9: Above ground ponding of water in South Dunedin for a $0.6 \mathrm{~m}$ mean sea level rise relative to the 2003-2015 average sea level (source [4]).

the maximum 2090 sea level rise scenario is estimated to be in the order of NZD\$148 million plus NZD\$18 million per annum in maintenance costs. For the Dunedin population of 100,000 , this could represent a significant increase in land tax.

'Managed retreat' was also mentioned as an option to be investigated, which drew severe criticism from the residents of South Dunedin, who wanted protection of their long established community. However, to create additional water storage at times of intense rainfall would require allowing parts of area to be flooded and protection of the remainder of the built-up areas through engineering works.

Many coastal cities in New Zealand and in other parts of the world can be expected to face similar issues whereby heavy rainfall events levels are exacerbated by the influence of sea level rise on groundwater, causing more frequent and greater magnitude flooding. Maintaining the existing drainage infrastructure is the first phase of logical engineering, but needs to be followed by developing solutions to account for the decreased water storage either by increased pumping capacity or by creating storage, via 'hump and hollow' modification of the land surface and change of land use.

To effectively develop these options, there is a need for better technical information on the nature of the sediment in the south Dunedin basin, the groundwater model within and its response to sea level rise. There is also a need for community education and consultation regarding the issues, the mitigation options available and the likely costs associated with them. 


\section{CONCLUSIONS}

South Dunedin has been developed on low lying, reclaimed salt marsh, protected by a dune barrier and embankment, and is now a low-lying basin. Groundwater levels close to the ground surface are influenced by the tide and the area is prone to flooding. Predicted future sea level rise will exacerbate flooding over the next 100 years or so.

To formulate effective solutions to future flooding, better technical information on the environment is required. There is a need for community education and consultation regarding the issues, mitigation options and the likely costs associated with them. The discussion has only just begun but is likely to evoke significant debate.

\section{ACKNOWLEDGEMENTS}

The author is grateful to the information provided by the Otago Regional Council, and particularly to Mike Goldsmith, who provided a review of the article, and Sharon Hornblow, who provided some of the figures. Belinda Smith Lyttle of GNS Science formatted the figures and Dr Simon Cox of GNS Science and David heron considerably improved the article with their review comments. Thanks also go to the Otago Daily Times for providing permission to publish attributed photos.

\section{REFERENCES}

[1] Parliamentary Commissioner for the Environment (PCE), Preparing New Zealand for Rising Seas: Certainty and Uncertainty, Wellington, New Zealand: Parliamentary Commissioner for the Environment, November 2015.

[2] Ministry for the Environment (MfE), Preparing for Coastal Change. A Guide for Local Government in New Zealand. Wellington, New Zealand: Ministry for the Environment, 2009.

[3] Department of Conservation (DoC), New Zealand Coastal Policy Statement. Wellington, New Zealand: Department of Conservation, November 2010.

[4] Goldsmith, M. \& Hornblow, S., The Natural Hazards of South Dunedin. Dunedin, New Zealand: Otago Regional Council Report, Otago Regional Council, July 2016.

[5] Rekker, J., The South Dunedin Coastal Aquifer \& Effect of Sea Level Fluctuations. Dunedin, New Zealand: Otago Regional Council, October 2012.

[6] Fordyce, E., Groundwater Dynamics of a Shallow Coastal Aquifer. Unpublished MSc thesis, Dunedin, New Zealand: Geography Department, University of Otago, December 2013.

[7] Beca Ltd., Assessment of Options of Protecting Harbourside and South City from Direct Impacts of Sea Level Rise. Auckland, New Zealand: Report prepared for Dunedin City Council. 2014. 